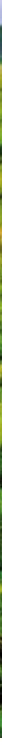

Iconic species such as the African elephant have been a focus of conservation efforts for many decades.

CONSERVATION

\title{
Bringing back wildlife
}

\section{A scholarly history of the WWF highlights the gap between advocacy and action, finds Nancy Lee Nash.}

$\mathrm{T}$ he conservation group WWF is now half a century old, and Saving the World's Wildlife documents that history. This is a splendidly researched and written work. But whoever came up with the title should be spanked and sent to sit in the nearest natural history library for as long as it takes to list every known species that has gone extinct or become seriously threatened since 1961.

Alexis Schwarzenbach's history is more about an organization than Earth's misery. Even the most optimistic current reports of the planet's wildlife survival status including every species from big mammals to birds, amphibians, fishes, trees, ferns, fungi and microorganisms - suggest there is little to celebrate. WWF International currently claims the largest membership, some 5 million, of any environmental organization worldwide. (Hong Kong, by comparison, has a population of 8 million.) Yet the WWF's success as a brand has eclipsed its original remit to protect species.

At its birth 50 years ago, the WWF was welcomed as a significant platform for conservation. Wildlife was both literally and metaphorically its middle name. It was created as a fund-raising organization to support the valuable scientific research of the
International Union for Conservation of Nature (IUCN), which was founded at a conference of the United Nations Educational, Scientific and Cultural Organization in 1948. A group of UK-based visionaries who were passionately focused on the urgent importance of saving endangered animals and plants set up the WWF. Meeting these

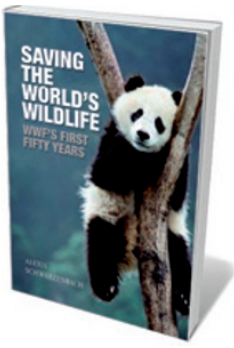

Saving the World's Wild life: WWF's First Fifty Years ALEXIS

SCHWARZENBACH

Profile Books: 2011. 352 pp. £25/\$39.95 signatory heroes in the book and learning about their pioneering work is inspiring.

Keen newcomers with a similar heartfelt mission arrived in later years, but the WWF continued in elder statesman mode - not least because of an impressive roll-call of royal stalwarts. Prince Bernhard of the Netherlands and Britain's Prince Philip were international presidents for many years each, and other royals were national presidents, adding allure, and commendable and significant support. The organization and its movers and shakers became widely known.

The WWF could have hired an agency to produce a glossy anniversary publication. Instead, to their credit, they commissioned an eminent Swiss historian. Schwarzenbach, who has previously written about Albert ${ }_{\Sigma}^{I}$ Einstein, studied WWF's scrupulously kept records and interviewed numerous living associates. None of them, he claims, tried to influence his interpretation of the WWF's history. It is all as precise as a Swiss watch.

Schwarzenbach faithfully records as much information about personalities, places and projects as his mission requires and space allows. Detailed notes, graphs and milestones are added in 30 pages of small print. Yet, surprisingly, these reveal that for almost half of those years there was hardly a pebble of significance. The period from 2004 to 2007 is empty of even a sand grain; 2008 is notable because "certified sustainable palm oil enters the market". Yet during the same years, most serious ecologists were focused on a larger issue: vast monoculture as one of the worst enemies of wildlife biodiversity.

The mid-1980s saw a major WWF International marketing

\section{$\rightarrow$ NATURE.COM} For more on saving the panda, see: go.nature.com/3dk65d 
makeover. It was allowed to trash co-founder Peter Scott's brilliant original panda logo. Anyone familiar with the living creature, as I am, finds that the WWF's present symbol looks more like a large black-and-white plastic dog than the panda in Scott's iconic rendering.

The 'Wildlife' in the title was also exchanged. 'World Wide Fund for Nature', a less evocative phrase, was now employed by WWF International headquarters and 29 of the 31 national organizations around the world. Steadfast WWF Canada and US refused to give up the original name. Knowing how strenuously these changes were fought at the time, it is surprising that the word 'wildlife' is resurrected in the title of this anniversary volume.

Many activists have found efforts in the past 25 years to be less a task of saving endangered animals than of employing them as 'poster critters' in yet another corner of modern business. Dispassionate as it is thorough, the book reveals some strange marketing strategies. Who would have thought the art of selling cigarettes internationally could morph into tactics to raise funds for conservation? Conservation is an expanding market and there are more than enough crises to go around.

The author generously mentions other respected groups from the distant past. He highlights important forebears of the WWF, including US bodies such as the Wildlife Conservation Society, established in 1895; the UK Royal Society for the Protection of Birds, set up in 1889; and many others. But negligible mention of Harold Coolidge, IUCN founder and 'father of wildlife conservation', will be regarded as a serious oversight by many.

All conservation groups rely on public and governmental support. Readers and historians in the future will have to decide whether their strategies for acquiring funding are being matched by their efficiency in conservation. Perhaps they will interview the men, for the most part, who appear in this book, shown in suits (safari, business and formal); at home at royal events and in corporate boardrooms; and in some cases like deer caught in headlights.

Rejuvenation of the planet's diversity cannot depend only on organizations, their marketing teams, and a few heroes. It rests on the shoulders of each of Earth's leading large-brained primates. Thoughtful ones wish us luck. @ SEE COMMENT P. 287

Nancy Lee Nash, WWF consultant 1979-84, wrote the proposal for ChinaWWF contact, the first foreign involvement in protection of the giant panda; was instrumental in establishing WWF Hong Kong; and is a Rolex Award and UNEP Global 500 Laureate for her project Buddhist Protection of Nature.

\section{Books in brief}

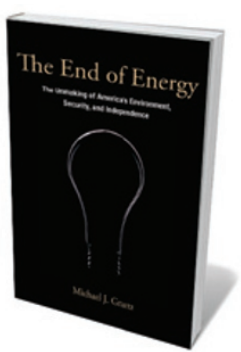

The End of Energy: The Unmaking of America's Environment, Security, and Independence

Michael J. Graetz MIT PRESS 384 pp. £22.95/\$29.95 (2011)

Energy policy has failed, according to law professor Michael Graetz. Pulling no punches, he argues that we must overcome the delusion we've lived with for 40 years that power is plentiful and cheap. By accepting inappropriate pricing of gas and oil, and being unwilling to negotiate around trade embargoes and for long-term solutions such as cap and trade, he argues that politicians have been complicit in distorting the energy market since the 1970s, with consequences for us all.

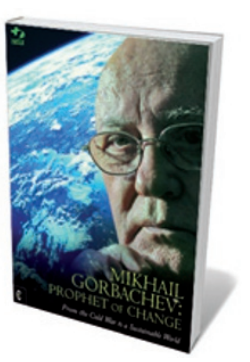

Mikhail Gorbachev: Prophet of Change: From the Cold War to a Sustainable World

Mikhail Gorbachev CLAIRVIEW Books 344 pp. £14.99 (2011)

As he turns 80, former Soviet president Mikhail Gorbachev publishes a selection of his writings and speeches on policy, philosophy and the environment. Since steering the cold war thaw of the 1980s, he has dedicated himself to supporting global peace, security and social justice as head of a non-governmental organization, Green Cross International. Having put sustainability at the centre of his cause, he has garnered the respect of many environmentalists and international leaders, who add tributes in this volume.

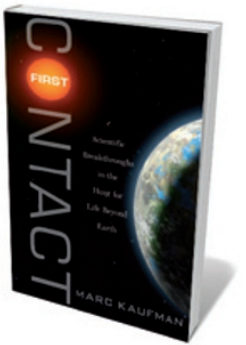

First Contact: Scientific Breakthroughs in the Hunt for Life Beyond Earth

Marc Kaufman SIMON \& SCHUSTER 224 pp. \$26.00 (2011)

Venturing from the mouth of an Alaskan volcano to the bone-dry Atacama desert in South America, to a hot South African mine, science writer Marc Kaufman gets to grips with the young field of astrobiology. He describes how microbes survive in the harshest conditions on Earth, suggesting that organisms might cling on in extraterrestrial places like Mars. And he interviews researchers he sees as adventurers as well as thinkers: part Carl Sagan, part Indiana Jones, part Watson and Crick.

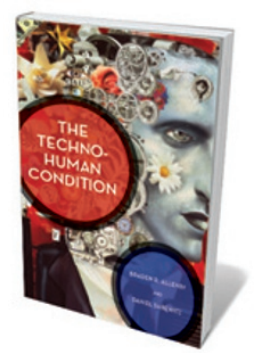

The Techno-Human Condition

Braden R. Allenby \& Daniel Sarewitz MIT PRESS 192 pp. $£ 18.95 / \$ 24.95$ (2011)

In this extended essay, ethicist and engineer Braden Allenby and science-policy expert Daniel Sarewitz explore what it means to be human in an age of technological extensions. From performanceboosting hormones and cognitive enhancements to re-engineered immune systems, our bodies and minds are being pushed into new evolutionary territories. They argue that terms such as human, technological and natural are outmoded, and should be rethought within a new techno-human relationship.

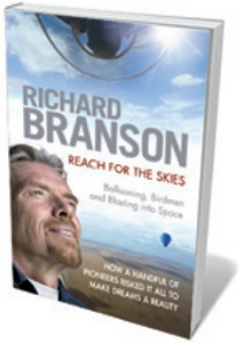

Reach for the Skies: Ballooning, Birdmen and Blasting into Space Richard Branson VIRGIN Books 352 pp. £18 (2010/2011) Intrepid balloonist, entrepreneur and founder of the Virgin Group, Richard Branson shares his love of aviation in his latest book. Charting the exploits of daredevil pilots and aerial technologists through the ages, from the lavish balloons of the Mongolfier brothers to the many record-breaking feats of his friend the late Steve Fossett, he heralds the risk-takers who have made everyday flying possible. He looks ahead to commercial space travel, which he hopes to establish through his own company, Virgin Galactic. 